\title{
Seasonal consumptive use of water by bell and Cubanelle peppers in semiarid and humid coastal sites in Puerto Rico'
}

\author{
Megh R. Goyal and Eladio A. Gonzalezz
}

\begin{abstract}
Consumptive use (CU) values were estimated for transplanted bell and Cubanelle peppers having a 120 -day growing cycle with 24 planting dates and 2 locations (Fortuna Substation, Juana Díaz and Isabela Substation, Isabela). Modified Blaney-Criddle model was used to estimate monthly consumptive use (CU) with temperature and rainfall data, $\mathrm{CU}$ at Fortuna was greater than $\mathrm{CU}$ at Isabela in all planting schedules. $\mathrm{CU}$ varied from 401 to $524 \mathrm{~mm}$ at Fortuna and 365 to $484 \mathrm{~mm}$ at Isabela. An example is presented to estimate seasonal net irrigation requirements (NIR) with CU.
\end{abstract}

\section{RESUMEN \\ Consumo estacional de agua para el pimiento en regiones semiáridas y húmedas de Puerto Rico}

Se estimó el consumo de agua (CU) para la época de siembra del pimiento en las Subestaciones de Fortuna e Isabela, Puerto Rico. La Subesfación de Fortuna, Juana Díaz, está localizada en la costa semiárida del sur y la Subestación de Isabela en la costa húmeda del norte. Se utilizaron 24 fechas de siembra de pimiento de trasplante para hacer el estudio. El modelo modificado de Blaney-Criddle se ufilizó para estimar el uso consuntivo (CU) mensual utilizando los datos de femperatura y lluvia. El CU fue mayor en la Subestación de Fortuna para todas las fechas de siembra, varió de 401 a $524 \mathrm{~mm}$. en Fortuna y en Isabela de 365 a $484 \mathrm{~mm}$.

\section{INTRODUCTION}

Adequate water supply for the entire growing season is essential for optimum vegetable production. Crop water requirement is supplied from rainfall and irrigation. In locations where sufficient rainfall is distributed throughout the growing period, irrigation need is minimal. In Puerto Rico, rainfall is unevenly distributed throughout the year (4) thus requiring functional irrigation facilities for successful vegetable production on the south and north coasts of Puerto Rico. For good water management and irrigation planning the irrigation requirements of crops must be

'Manuseript submitted to Editorial Board 10 May, 1988.

This study was conducted under USDA Grant No. 85-CSRS-2-2664, project CBAG-PR-23, "Irrigation Requirement Estimations in Puerto Rico".

"Associate Agricultural Engineer and Research Assistant, Agricultural Experiment Station, University of Puerto Rico, Mayagüez Campus, Rfo Piedras, P. R. 
known or estimated $(1,6)$. USDA Technical Release No. 21 covers procedures to estimate irrigation water requirements on a farm or on a project (6). Hackbart (3) has developed a computer program to estimate net irrigation requirements for various crops with the Blaney-Criddle model (1) and USDA Technical Release 21.

This study estimated total consumptive use of transplanted bell and Cubanelle peppers for 24 planting schedules at Fortuna and Isabela Agricultural Experiment Substations in Puerto Rico.

\section{MATERIALS AND METHODS}

Table 1 shows average temperature (5), average rainfall (2) and percent day light (6) for Fortuna and Isabela agricultural experiment substations. Monthly consumptive use of sweet peppers was estimated with climatic data in table 1, computer program (3) and the following relationship (6):

$$
\mathrm{CUm}=\mathrm{K}_{\mathrm{c}} \times \mathrm{K}_{\mathrm{t}} \times \mathrm{H} \times \mathrm{p} \times(0.455 \times \mathrm{T}+8.128)
$$

where CUm $=$ monthly consumptive use $(\mathrm{mm}), \mathrm{K}_{\mathrm{t}}=\mathrm{a}$ climatic coefficient which is related to mean air temperature (6), $\mathrm{H}=$ humid area factor of $0.8, \mathrm{p}=$ monthly percentage of daylight hours in the year (1, 6), $\mathrm{T}=$ mean air temperature in ${ }^{\circ} \mathrm{C}$, and $\mathrm{K}_{\mathrm{c}}=$ crop coefficient reflecting growth stage (6). $\mathrm{K}_{\mathrm{c}}$ was 0.53 for $0-30$ days, 0.78 for $31-60$ days, 1.02 for 61-90 days and 0.95 for 91-120 days. Average $K_{c}$ was 0.82 .

Monthly CUm was then summed to obtain totaled consumptive use (CU). The twenty-four planting schedules were the 1st and 16th of each

TARLE 1.-Climatic data for Fortana and Isabela Substations

\begin{tabular}{|c|c|c|c|c|c|c|}
\hline \multirow[b]{2}{*}{ Month } & \multicolumn{3}{|c|}{ Fortana } & \multicolumn{3}{|c|}{ Isabela } \\
\hline & $\begin{array}{l}\text { Temperature } \\
{ }^{\circ} \mathrm{C}\end{array}$ & $\begin{array}{c}\text { Rainfall } \\
\mathrm{cm}\end{array}$ & $\underset{\%}{\text { Daylight }}$ & $\begin{array}{l}\text { Temperature } \\
{ }^{\circ} \mathrm{C}\end{array}$ & $\begin{array}{c}\text { Rainfall } \\
\mathrm{cm}\end{array}$ & $\underset{\%}{\text { Daylight }}$ \\
\hline January & 24.5 & 2.18 & 8.00 & 23.1 & 9.65 & 7.97 \\
\hline February & 24.3 & 2.72 & 7.18 & 23.0 & 8.48 & 7.18 \\
\hline March & 24.8 & 1.55 & 8.25 & 23.6 & 8.26 & 8.26 \\
\hline April & 25.7 & 5.79 & 8.28 & 24.2 & 12.29 & 8.30 \\
\hline May & 26.5 & 11.40 & 9.16 & 25.1 & 21.44 & 9.17 \\
\hline June & 27.2 & 8.92 & 9.18 & 25.7 & 19.15 & 9.16 \\
\hline July & 27.5 & 6.96 & 8.92 & 26.2 & 12.70 & 8.95 \\
\hline August & 27.6 & 11.91 & 8.72 & 26.2 & 16.97 & 8.75 \\
\hline September & 27.4 & 15.06 & 8.25 & 26.1 & 17.53 & 8.25 \\
\hline October & 27.1 & 13.49 & 8.24 & 25.7 & 16.56 & 8.23 \\
\hline November & 26.3 & 9,40 & 7.91 & 25.0 & 13.77 & 7.88 \\
\hline December & 25.2 & 3.40 & 7.91 & 23.9 & 10.97 & 7.88 \\
\hline Annual & - & 92.79 & - & - & 167.77 & - \\
\hline
\end{tabular}


J. Agric. Univ. P.R. vol. 72, No. 4, OCTOBER, 1988

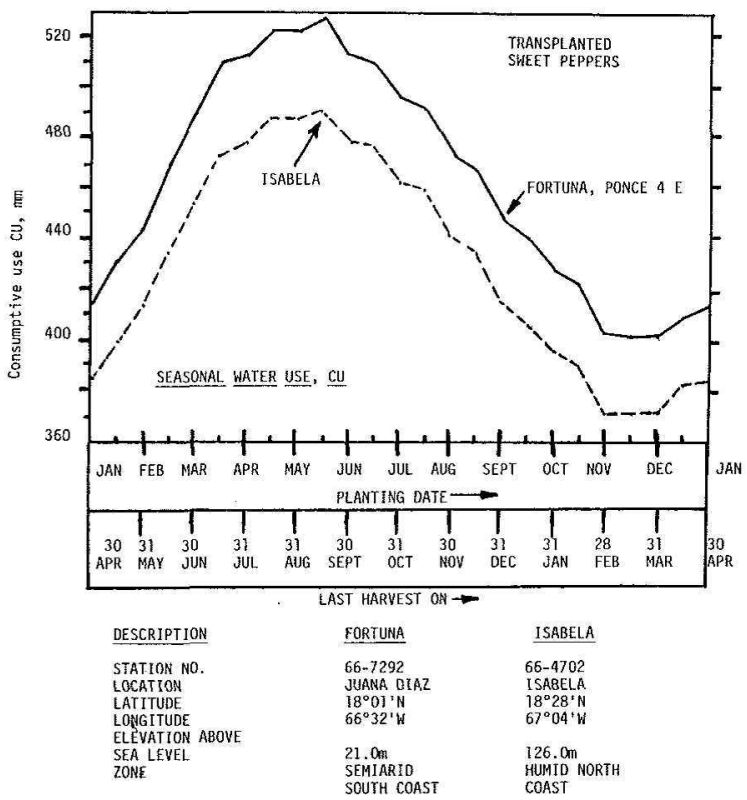

F1G. 1.-Total consumptive use of peppers for 24 planting dates at Fortuna and Isabela Agricultural Experiment Substations, Puerto Rico.

month January through December. Last harvest was 120 days after transplanting.

\section{RESULTS AND DISCUSSION}

Table 1 shows climatic data for Fortuna and Isabela agricultural experiment substations. Mean monthly temperature was higher at Fortuna than at Isabela for January through December. Lowest temperature was in February and highest temperature was in July. Mean monthly temperature variation between Fortuna and Isabela was 1.2 to $1.5^{\circ} \mathrm{C}$ in January through December. Annual rainfall was $1,678 \mathrm{~mm}$ at Isabela and $928 \mathrm{~mm}$ at Fortuna. Percent day light difference between Fortuna and Isabela was 0.03 percent in January, November, December; 0.0 in February, 
June, September; 0.01 in March, May; 0.02 in April; 0.03 in July, August; and 0.01 in October.

Figure 1 shows total water use (CU) for 120-day transplanted sweet peppers and 24 planting dates at Fortuna and Isabela agricultural experiment substations. CU varied from 402 to $526 \mathrm{~mm}$ at Fortuna, and 372 to $490 \mathrm{~mm}$ at Isabela. CU was minimum when peppers were transplanted 16 November. It was maximum for transplanting 16 May because of high temperatures. For all 24 planting dates, CU at Fortuna was greater than CU at Isabela. This difference is due to higher monthly temperatures at Fortuna than at Isabela.

Because of higher commercial yield, better fruit quality and lesser cost per hectare, peppers are generally transplanted in November through February in the ecological zones of Fortuna and Isabela $a^{\text {s. It is }}$ therefore advised to consult the local agricultural extension agent for optimum planting date before selecting CU for a particular season. However, small farmers plant during other months. Experimental research to determine $\mathrm{K}_{\mathrm{c}}$ in Puerto Rico is lacking. These CU values were estimated with $\mathrm{K}_{\mathrm{c}}$ corresponding to areas similar to Puerto Rico. The following examples indicate how to utilize $\mathrm{CU}$ for irrigation requirements.

Example I. Estimate the consumptive use for transplanting sweet peppers on 1 December at Fortuna and Isabela. Use an average $\mathrm{K}_{\mathrm{c}}$ of 0.79 instead of 0.82 .

From figure 1 , CU is $374 \mathrm{~mm}$ at Isabela and $403 \mathrm{~mm}$ at Fortuna with average $\mathrm{K}_{\mathrm{c}}$ of 0.82 and 01 December transplanting. $\mathrm{CU}$ at Isabela = $(374 / 0.82) \times 0.79=360 \mathrm{~mm}$ and CU at Fortuna $(403 / 0.82) \times 0.79=388$ $\mathrm{mm}$ during the growing cycle. This example shows procedures of how to estimate $\mathrm{CU}$ with a new $\mathrm{K}_{\mathrm{c}}$.

Example II. Estimate total water requirement for a low pressure trickle irrigation system with the following data:

$\begin{array}{lll}\text { Description } & \text { Fortuna } & \text { Isabela } \\ \text { Soil pH } & 7.9 & 5.4 \\ \text { Soil type } & \begin{array}{l}\text { San Antón (Mollisol) } \\ \text { (fine-loamy, montmori- }\end{array} & \begin{array}{l}\text { Coto clay (Oxisol) } \\ \text { (kaolinitic, iso- } \\ \text { hyperthermic, Tropeptic }\end{array} \\ & \begin{array}{l}\text { Honitic, isohyper- } \\ \text { thermic, Cumulic }\end{array} & \text { Haplorthox) } \\ & \text { Haplustolls) } & 7.5 \mathrm{~cm} \\ \text { Field capacity, depth } & 7.5 \mathrm{~cm} & 60 \mathrm{~cm} \\ \text { Root depth } & 60 \mathrm{~cm} & 50 \% \\ \text { Allowable depletion } & 50 \% & 5.0 \mathrm{~cm} \\ \text { Initial soil moisture } & 3.75 \mathrm{~cm} & \\ \text { Irrigation method } & \begin{array}{l}\text { drip line with } 60 \mathrm{~cm} \\ \text { orifice spacing }\end{array} & \\ & \end{array}$

${ }^{3}$ Personal communication. Vegetable Program, Office of the Land Authority of Puerto Rico, Santa Isabel, P. R. 


$\begin{array}{lll}\text { Irrigation efficiency (1) } & 80 \% & 80 \% \\ \text { Crop } & \text { Peppers } & \text { Peppers } \\ \text { Growing Cycle } & \text { 120 days } & \text { 120 days } \\ \text { Planting date } & \text { 1 December } & \text { 1 December } \\ \text { Last harvest } & 31 \text { March } & 31 \text { March } \\ \text { Row spacing } & 180 \mathrm{~cm} & 180 \mathrm{~cm} \\ \text { Plant spacing } & 30 \mathrm{~cm} & 30 \mathrm{~cm} \\ \text { Planting pattern } & \text { Zizgag on both sides of } & \\ \text { Plants per ha } & 37,037 & \\ \text { Average Ke } & 0.82 & 37,037\end{array}$

From figure 1, CU is $374 \mathrm{~mm}$ at Isabela and $403 \mathrm{~mm}$ at Fortuna with an average $K_{c}$ of 0.82 and 1 December transplanting. Effective rainfall (ER), net irrigation requirements (NIR), gross irrigation requirements (GIR) were estimated with a computer program (6) and the following equations $(1,3,6)$ :

$$
\begin{aligned}
& \mathrm{ER}_{\mathrm{m}}=\left(0.70917 \times \mathrm{I}^{0.82416}-0.11556\right) \times 10^{0.02426 \mathrm{CUM}} \times \mathbf{f} \ldots \ldots \ldots . / 2 / \\
& \mathrm{f}=0.531747+0.295164 \times \mathrm{D}-0.057697 \times \mathrm{D}^{2}+0.003804 \times \mathrm{D}^{3} . / 3 / \\
& \mathrm{ER}=\left(\mathrm{ER}_{\mathrm{Dec}}+\mathrm{ER}_{\mathrm{Jan}}+\mathrm{ER}_{\mathrm{Feb}}+\mathrm{ER}_{\mathrm{Mar}}\right) \times 25.4 \ldots \ldots \ldots \ldots .14 /
\end{aligned}
$$

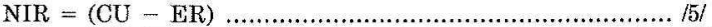

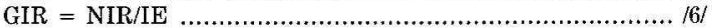

where, $\mathbf{E R}_{\mathrm{m}}=$ monthly effective rainfall (inches), $\mathrm{I}=$ monthly mean rainfall (inches), $\mathrm{CU}_{\mathrm{m}}=$ given by equation $/ 1 /$ and divided by 25.4 (inch$\mathrm{es}), \mathrm{f}=$ given by equation $/ 3 /, \mathrm{D}=$ net depth of application (inches), $\mathrm{ER}$ $=$ total effective rainfall $(\mathrm{mm}), \mathrm{NIR}=$ total net irrigation requirements $(\mathrm{mm}), \mathrm{CU}=$ total consumptive use $(\mathrm{mm})$, GIR = gross irrigation requirements during the crop $(\mathrm{mm})$ and $\mathrm{IE}=$ irrigation effeciency (in fraction).

ER is $133 \mathrm{~mm}$ at Isabela and $48 \mathrm{~mm}$ at Fortuna. NIR is $241 \mathrm{~mm}$ at Isabela and $355 \mathrm{~mm}$ at Fortuna. Gross irrigation requirement during the 120-day crop is therefore $444 \mathrm{~mm}(=355 / 0.80)$ at Fortuna and $301 \mathrm{~mm}$ $(=241 / 0.80)$ at Isabela. This example shows the procedure of how to utilize $\mathrm{CU}$, rainfall data and management factors for estimating gross total irrigation requirements.

\section{LITERATURE CITED}

1. Burman, R. D., P. R. Nixon, J. L. Wright and W. O. Pruitt, 1980. Water requirements. $I n$ : Design and Operation of $\mathbf{F}$ arm Irrigation Systems, edited by $\mathbf{M}$. E. Jensen, American Society of Agricultural Engineers, St. Joseph - MI, Monograph No. 3, Pages 189-225.

2. Climatography of the United States No. $86-45$ of Puerto Rico and U. S. Virgin Islands. In: Climatic Summary of the US-Supplement. United States Department of Com. merce, Washington, D. C.

3. Hackbart, C. A., 1987. Conuse and SCS User's Manual. USDA-SCS, Fort Worth, Texas.

4. Ravalo, E. J., M. R. Goyal and C. R. Almodovar, 1986. Average monthly and annual rainfall distribution in Puerto Rico. J. Agric. Univ. $P$. R. 70 (4):267-75. 
5. Temperature data. Puerto Rico and U. S. Virgin Islands, updated 1984. National Climatic Data Center, Asheville, NC 28801.

6. United States Department of Agrieulture - Soil Conservation Service, 1970. Irrigation water requirements. Eng. Div. Tech. Release No. 21. U. S. Govt. Printing Office, Washington, D. C. 